\title{
Phytoremediation of Heavy Metals Extracted from Soil and Aquatic Environments: Current Advances as well as Emerging Trends
}

\author{
Rohit Kumar Verma ${ }^{1(\mathbb{D})}$, Mahipal Singh Sankhla ${ }^{2, *(\mathbb{D})}$, Ekta B. Jadhav ${ }^{3(\mathbb{D})}$, Kapil Parihar ${ }^{4(\mathbb{D})}$, Kumud \\ Kant Awasthi 5 (D) \\ 1 Dr. APJ Abdul Kalam Institute of Forensic Science \& Criminology, Bundelkhand University, Jhansi, India; \\ rohitlyn8423@gmail.com (R.K.V.); \\ 2 Department of Forensic Science, Vivekananda Global University, Jaipur, India; mahipal4n6@gmail.com; (M.S.S.) \\ 3 Department of Forensic Chemistry and Toxicology, Government Institute of Forensic Science Aurangabad, Maharashtra, \\ India; ekta.4n6@gmail.com (E.B.J.); \\ 4 State Forensic Science Laboratory, Jaipur, Rajasthan, India; kparihar94@gmail.com (K.P.); \\ 5 Department of Life Science, Vivekananda Global University, Jaipur, India; kumud.awasthi@ vgu.ac.in (K.K.A.); \\ * Correspondence: mahipal4n6@gmail.com (M.S.S.);
}

Received: 8.07.2021; Revised: 29.08.2021; Accepted: 5.09.2021; Published: 19.10.2021

Abstract: Quick industrial development, current farming practices, and other anthropogenic events enhance an important number of poisonous heavy metals in the atmosphere, which persuades severe poisonous effect on all the forms of living beings, which change the properties. This type of heavy metal pollution has ecological dangers as well as affects human health. Heavy metal contamination is mutagenic, endocrine, carcinogenic, and teratogenic, which causes nervous health problems mostly in kids. Further, an appropriate method for the remediation of adulteration of water along with soil is phytoremediation. In addition, it has been progressively utilized. Phytoremediation helps to improve the contaminated soil and water by the extraction of contaminating heavy metals, which is called phytoextraction and their phytostabilisation. Phytoremediation is based on many processes, and it is very ecofriendly, cost-effective, and economical. In this review, we aim to explain the detailed study of phytoremediation and current approaches.

Keywords: heavy metals; water; contamination; phytoremediation.

(C) 2021 by the authors. This article is an open-access article distributed under the terms and conditions of the Creative Commons Attribution (CC BY) license (https://creativecommons.org/licenses/by/4.0/).

\section{Introduction}

Today the world is facing many issues, and one such issue is heavy metal pollution. The movement of heavy metals during removal from ores and succeeding development for various uses resulted in the discharge of such elements to the surrounding. The issue of effluence due to heavy metal deposition is getting dangerous due to accumulative industrial development as well as the messing up of regular biogeochemical cycles. In contrast to the carbon-based constituents, these metals are major non-biodegradable; thus, they gather into the environment. The build-up of these heavy metals in aquatic life and earth is a reason to threaten the environment and all living beings' human life and health. These components get collected and add up in the body soft tissue of organisms consuming it unknowingly (bioaccumulation). 
The amount of these harmful elements rises as they go from minor trophic rank to upper trophic rank (this phenomenon is known as bio-magnification). On the earth's surface, these heavy metals result in toxicological disturbances to organisms residing in the soil layer that can reduce their living population and their functioning [1]. The fact that flora is used as environmental remediation is ancient cannot be sketched to any specific foundation; though, a row of interesting scientific encounters pooled to an interdisciplinary study approach that has permitted the expansion of this knowledge into encouraging ecological machinery, which is known as phytoremediation. It is, defined as the application of green flora put into separate out the contaminant, which causes the pollution to the ecosystem or condense them, harmless. As potential remediation, a resolution to thousands of polluted locations in the US as well as abroad. Aquatic life and the soil layer that is adulterated by metals remain a chief environmental and human health issue that needs to be impacted effectively, along with getting a reasonably priced technological solution. The nonradioactive $\mathrm{Zn}, \mathrm{Hg}, \mathrm{Pb}, \mathrm{Cu}, \mathrm{As}$, and $\mathrm{Cd}$ plus radioactive $\mathrm{Cs}, \mathrm{Sr}$, and $\mathrm{U}$ (that are denoted here as toxic metals) are the supreme biologically significant metallic contaminants. Microbial bioremediation has been slightly an effective ingredient involved in the deprivation of certain organic toxins. Nevertheless, it is futile to account for the challenge of toxic metal contamination, predominantly on the earth's surface. Even though organic molecules could be tarnished, contaminated metals can alone be remediated by isolating them from the soil layer. The recent technology for the crackdown of harmful metalcontaminated topsoil is the diggings and the burial of the soil at a lethal waste region at the cost of $\$ 1000000$ per acre, which is an average. In the states alone, $\$ 300$ billion is the minimum calculated charge for cleaning or eliminating the pollutants from the regions, which contain deadly and radioactive metals. The difficulty level is worse in acute abroad, specifically during the contamination at a larger scale covering a wider area with radionuclides, such as areas adjacent to the Chernobyl nuclear reactor. This technology of phytoremediation of metals is worthwhile and effective to its cost of investing. Thus, this method is also known as 'green' technology built on the application of metal-accumulating flora to isolate and extract out toxic metals, comprising radionuclides, from the soil as well as water. Phytoremediation has grown into a matter of passionate public along with being a scientific interest as well as it becomes a topic of several modern reviews [2-5]. While plants can deal with major damage by extreme interaction with heavy metals, they also depend on a wide range of transition (heavy) metals as crucial micronutrients for regular evolution as well as advancement. Surrounded by metals, even some encompass elements, which are vital for maximum redox reactions besides they are essential for regular cellular activities. Fe is a crucial factor of haem proteins like catalase, cytochromes, and Fe-S proteins (e.g., ferredoxin). A fundamental element of specific electron transmission proteins is $\mathrm{Cu}$ in photosynthesis (e.g., plastocyanin) and respiration (e.g., cytochrome c oxidase) processes, whereas Mn has lower redox activity yet plays a major role in photosynthesis (e.g., $\mathrm{O} 2$ evolution). In various proteins and enzymes, $\mathrm{Zn}$ is non-redox active but has a vibrant structural plus catalytic role. $\mathrm{Ni}$ is a component of urease and the minute amount of $\mathrm{Ni}$, which are crucial for certain floral species [6]. On a decrease in the concentration of these metals, a variety of deficiency symptoms appear as well the growth is reduced. In addition, if present in a larger amount, the transition metals disrupt cell function, alter normal metabolic processes to produce cell damage, and may even lead to death. Many molecules are targeted at cells whose structure/function is restricted, modified, or enhanced by mutation molecules [7] lists three measures that yield plant toxins with transition (heavy) metals. These are replacing important substances in biomolecules. To inhibit the vital biological functions of 
molecules. Transformation of enzymes/proteins, plasma membranes, and/or transport structure/membranes. Enzymes and proteins contain many mercapto ligapto that can bind to physically chelate metals, thus causing these proteins to lose their active properties. Heavy metals moreover produce oxidative stress that is arbitrated by the production of free radicals [8]. Some heavy metals directly affect chemical plus physical methods by constraining photosynthesis and respiration, resulting in minimized growth [9]. Thus, extreme accumulation of such heavy metals in plants can cause toxicity by altering important protein composition or restoring vital elements indicated by chlorosis, impaired growth, root rot, and impaired image systems, among other effects [10,11]. Heavy metals are considered one of the fatal inorganic pollutants from large parts of anthropogenic activities [12]. Manufacturing units are the main foundations of environmental deprivation as it releases numerous verities of contaminants, for example, heavy metals [e.g., Zinc ( $\mathrm{Zn})$, chromium (Cr), cadmium $(\mathrm{Cd})$, arsenic (As), etc.] also the toxic organics [13-15]. These heavy metals cannot decay naturally (due to their nature) and are durable in soil and water. The quality of agricultural crops and groundwater will also deteriorate as a result of their transfer from contaminated soil, as reported by other researchers [16-19]. Globally, the aquatic environment is in dire straits due to a combination of various toxic substances, including hydrocarbons, pesticides, antibiotics, cosmetics, and toxic heavy metals [20,21,22]. High concentration of heavy metals, fluoride, nitrate, etc. It has been found above permissible groundwater levels in many parts of the world, including India [23,24]. According to reports from the World Health Organization (WHO) as well as the United Nations Children's Fund (UNICEF), except in developing countries, around 2.2 million people dying yearly because of prolonging consumption of poor-quality water for drinking along with such degraded sanitation [25]. The absorption of heavy metals by plants badly disturbs the evolution as well as the rise in the amount of iron in the soil distresses the crop yields plus symbiosis. It dislocates the membranes that act as genotoxic elements and disperse cell organelles [26, 27]. The preparation of heavy metals is challenging in the soil as heavy metals cannot be biologically destructive also can not be destroyed naturally but can only be converted from one form of oxidation to another along with removal from one organic compound to reduced or less toxic. Physical, biological, and chemical processes are applied for lessening and eliminating harmful contaminants from polluted areas, and among these, these biological processes are apt to date. Organic deprivation is simple, worthy of its cost as well as harmless compared to other physicochemical approaches plus the machinery [26,28]. $\mathrm{Hg}, \mathrm{Ni}, \mathrm{Cr}, \mathrm{Pb}$, $\mathrm{Cd}$, and As, known to be heavy metals, devour high stability as well as can lessen biodegradability $[29,30]$. As a result of their frequent dumping in water and land, human health has become increasingly vulnerable to many serious diseases [31,32]. Options for diagnosing and correcting any problems are at the heart of the research. Therefore, in the present paper, many of the most widely used and advanced options for determining heavy metals in water and soil environment have been reviewed in detail. Other remedial measures are also included in reducing the toxicity of heavy metals in water and soil. The term "phytoremediation" is a combination of Greek "phyto" (meaning plant) and Latin "remedium" (meaning to correct or remove evil). Green plants have a great ability to pick up pollutants and carry out their functions in various ways. Phytoremediation technology is the latest technology to come up with the most extensive research studies in the last two decades (1990 onwards). The concept of phytoremediation (such as phytoextraction) [33]. The knowledge is fun and has a good reception in the community. It is appropriate to apply to very large sites where alternative remedies are less expensive or more efficient [34]. Phytoremediation has lower installation and 
repair costs compared to other repair options [35]. In terms of cost, phytoremediation can cost less than $5 \%$ of other cleaning methods [36]. The formation of grass in contaminated soil also helps prevent erosion and leakage of iron [37]. From an economic point of view, the goal of environmental degradation can be tripled: phytostabilization; phytoextraction of metals at a market value such as $\mathrm{Ni}, \mathrm{Tl}$, and $\mathrm{Au}$; long-term land management where phytoextract extraction gradually improves soil quality for subsequent cultivation of crops with high market value [38]. Using phytoremediation has a number of advantages.

\subsection{Economically possible.}

Phytoremediation is an autotrophic system driven via solar energy, consequently, easy to handle. Also, the cost of setting up plus the cost of maintenance is less too.

\subsection{Environment as well eco-friendly.}

This may result in decreased disclosure of the contaminants to the environment as well as the ecosystem.

\subsection{Applicability.}

It may be useful to a wide-area field plus can effortlessly be disposed of. It stops and avoids soil erosion and metal leaching by stabilizing heavy metals, decreasing the threat of contaminant pollution. It also develops soil richness through discharging numerous organic matters, which increases soil fertility. All through the past years, much research has been directed to recognize the molecular mechanisms underlying heavy metal tolerance and bring advancement in tools and techniques to expand phytoremediation competence. In the present review, the mechanisms of how heavy metals are consumed as well as translocated in flora are explained. Also, the purification policies (avoidance and tolerance) inculcated in plants in reply to heavy metals have been discussed. The main agenda is to overlook the current improvements of advancing phytoremediation techniques, involving the schemes of enhancing the heavy metal biological readiness, concentration, and tolerance [39,40,41].

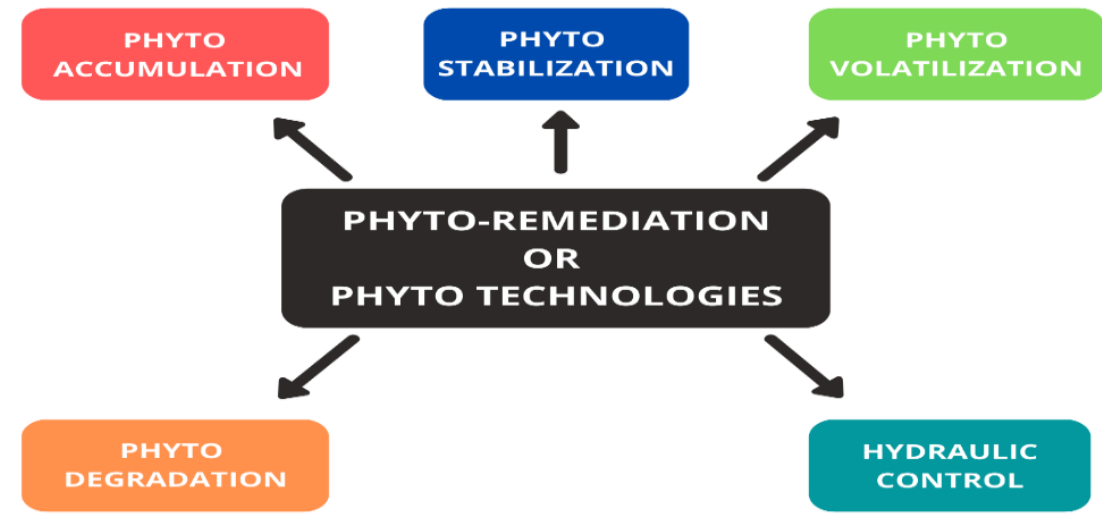

Figure 1. Various mechanisms in phytoremediation.

\section{Heavy Metals Contamination and Toxicity}

\subsection{Aquatic ecosystem}

The concentration of harmful (heavy) metals at different ecological compartments remains a giant risk to various biotic communities, the surrounding, and the biological 
concentration of such harmful elements at succeeding trophic strata via biomagnification. This has increased the gravity of the problem [42]. Compared with the organic contaminants, the mainstream metals/metalloids have not undergone any chemical or microbial disintegration or ruin, leading to a ceaseless upsurge in the quantity of such lethal metals, resulting in prolonged soil toxicity [43]. The constant enhancement of such lethal elements in aquatic as well as soil ecosystems is the major global distress $[44,45]$. Thus the pursuit of innovative technological improvement has contributed to the brutality of this adulteration that threatens the existing biotic communities' survival $[46,47]$. The consequence degraded water quality plus water borne-human health risks even at lower doses of heavy metals $[48,49,50]$. Heavy metals, for example, cadmium, lead, chromium, mercury, aluminum, copper as contaminants in water, are devised by anthropogenic triggers, plus natural occurrences such as forest fires, volcanoes, and seepage from rocks. In a period, the heavy metals enter the food-chain ecological concept via water resources. These chronic effects could be revealed in some years. Also, it may employ numerous intimidations, for example, different types and degrees of cancer, pain in joints, mental disorders, and gastric disorders. The living population residing beside and around industrial areas is exposed to heavy metals. Moreover, malnutrition children and pregnant women are at high risk of getting affected by this harmful heavy metal and its toxic reactive function. The freshwater sources are widely concentrated by pathogens deposited by crude or lack of treated wastewater plus the heavy metals by-products released from mining sites as well as industrial waste [51]. The serve reports show that greater than $80 \%$ of the global wastewater is deposited in the surrounding environment deprived of proper management. This is the chief reason for nearly 58\% of diarrheal disease (a major cause of child mortality) [52]. Therefore, the coming future will lessen this world's risk of bad water quality through proper remediation measures. Also, the practices are also essential for treating the water to enhance its quality. In that context, fungal phytoremediation functions as a pocket-friendly, environment-friendly and dependable technique. In a river contaminated using base-metal mining, cadmium was the prominent relocating element and possibly bioavailable metal and was principally hunted by non-detrital carbonate minerals; organic matter also the iron-manganese oxide minerals [53]. Even though mercury is the most regularly dealt with element, as they exist in the environment, human interference and continuous activity have resulted in a significant rise of mercury discharge into the atmosphere, aquatic environment, and the troposphere [54]. [55] Recommended that the most vital anthropogenic bases of mercury contamination in the aquatic resource are urban discharges, atmospheric deposition, mining, agricultural material runoff, discharges, and industrial fossil fuel use, pharmaceutical production, and burning of coal [55]. The aquatic ecosystem is a cost-effective and resourceful cleanup method for phytoremediation of a wide area of contaminated zones. Aquatic plants are known as natural absorbers because they absorb pollutants as well as heavy metals [56]. Elimination of various heavy metals and various other impurities by using aquatic plants is the greatest skilled plus profitable process [57,58]. Fabricated wetlands and aquatic plants were expansively useful worldwide for the management of untreated water $[59,60]$. The assortment of underwater species for heavy metal build-up is the key process for enhancing phytoremediation [61,62]. Elimination of harmful contaminants is the utmost significant step to reduce the risk to all living beings, especially the human population, as they would be the ultimate consumer and the surrounding location. The various techniques used for such isolation method, for example, reverse osmosis [63], ion exchange [64], chemical precipitation [65], adsorption and solvent extraction [66], include massive operational as well as the maintenance costs also they are usually not an eco-friendly 
[65-68]. These conservative procedures for the remediation of heavy metals are normally expensive as well as time taking one too. These treatment methods need a good amount of cost investment and produce an issue of sludge discard [69]. For the remediation of wastewater polluted with heavy metals contaminants, environmentally friendly as well as inexpensive management technology is ensured [70,71]. The latest research demonstrates eco-friendly measures for phytoremediation for the elimination of harmful contaminants for a longer period. Still, this review article condenses the potential application of underwater flora in phytoremediation to manage untreated/poor quality water[72].

\subsection{Soil ecosystem}

The rate of faster improvement of the industrial sector has raised the heavy metal contamination problem, like a hike in manufacturing purposes for other metals. Heavy metals like cadmium, lead, arsenic, chromium, copper, and zinc are largely applied through industries, agriculture; these metals are extremely deadly at a fewer amount. Such metals naturally occur in the environment, but adulteration occurs when the amount of such metals is greater in the land region because of continuous mining as well as smelting events [73]. The soil (endophytic and rhizobium) microorganisms present a vital part in the improvement of phytostabilization. The favorable bacteria helps phytoremediation technology by enhancing the accumulating rate and arresting heavy metal movement [74].

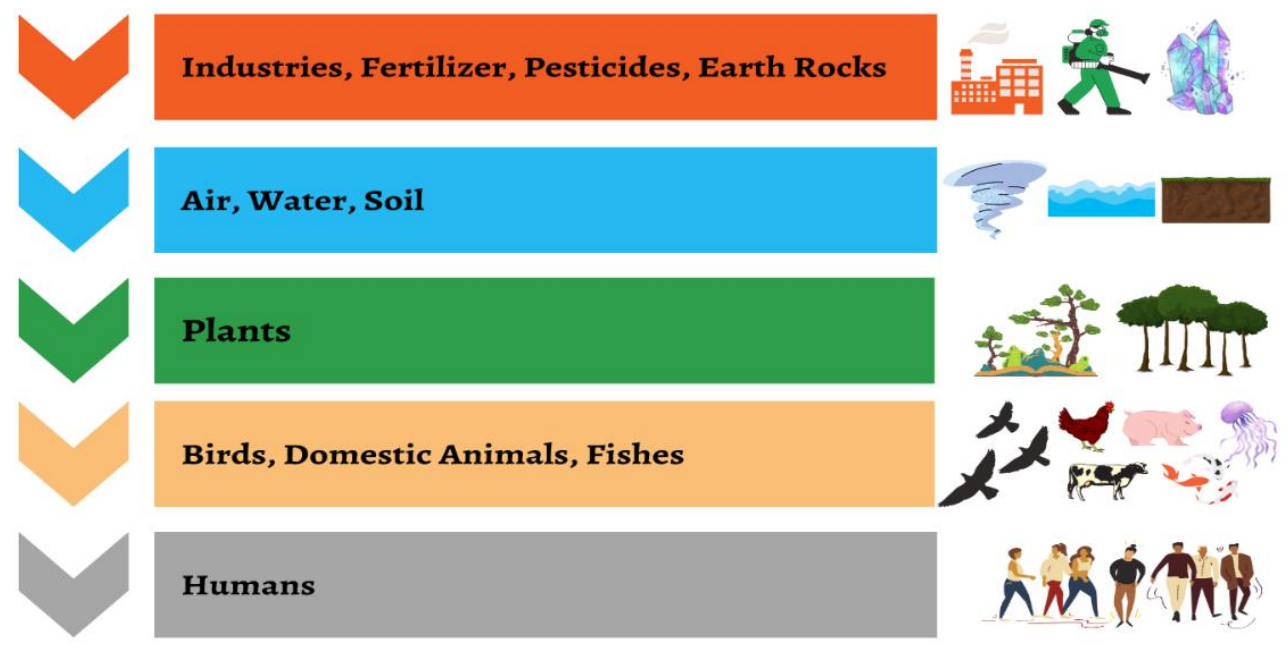

Figure 2. Cause of heavy metal pollution along with its cycle in the environment.

Earlier, when there was no improved technology usage to bring out soil remediation, the heavy metal-polluted patches of soil were controlled by onsite administration or mining or disposing of a landfill area. On the other hand, this procedure has not fully ceased this heavy metal issue. Instead, they have alone removed heavy metal-polluted soil after the contaminated site to landfill. With the advancement in remediation methods and technologies, various physical and chemical methods are considered to encompass such issues. Still, these methods are expensive; also, their application is difficult and complicated [75, 76]. There are chances and possibilities that this method causes disturbance to the native surrounding. Furthermore, the chemical methods can generate secondary contamination issues that a greater capacity of sludge will be produced as well as upsurge the expense of sludge treatment [77]. However, numerous heavy metals captivated by the flora get transferred to a volatile form also consequently discharged to the surrounding through the procedure known as phytovolatilization. Some volatile heavy metals such as $\mathrm{Hg}$ and $\mathrm{Se}$ are isolated from this 
process from contaminated soils patches [78]. Under the ground, the heavy metals are consumed and absorbed by the plants via the cortical tissues present in roots because of their correspondence to some necessary micronutrients (such as zinc) as well as implemented to reach the xylem transport system for symplastic and/or apoplastic pathway [79]. Heavy metals become the major reason for limited plant growth or reduction in their height because of declining photosynthesis rates as well as chlorophyll amount [80]. In plants, metals can be a reason for water tension due to diminishing stomatal conductance, rate of transpiration, plus comparative leaf amount of water because of reduction in magnitude as well as the number of xylem vessels, cell enlargement, and chloroplasts [81].

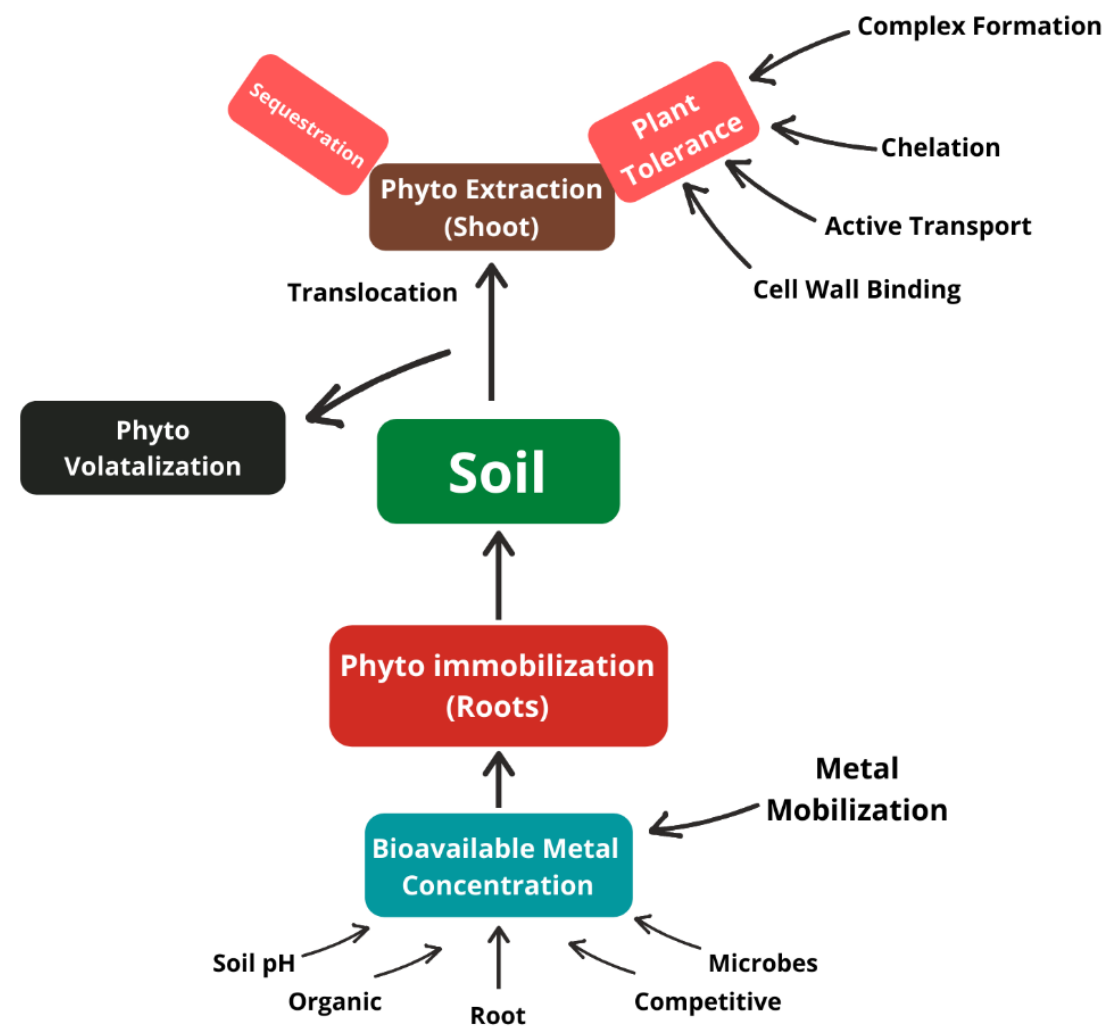

Figure 3. Mechanisms involved in phytoremediation of heavy metals/ metalloids in soils.

\section{Phytoremediation: Applications and challenges}

Assessment of numerous field-scale usage displays that phytoremediation is on an average $50 \%$ less costly compared to digging the sites, thus making it cheaper than bioremediation [82, 83], in agreement with additional data [84]. Few outdated remediation procedures usually have disadvantages, for example, producing atmospheric releases, a greater quantity of extra wastes, which involve dumping along with not appropriate for the healthy management of soil that is to be recycled and used for agronomic usage or other corresponding purposes of plant/biomass manufacture [85]. Many have claimed that the marketable accomplishment of phytoremediation relies on the production of suitable biomass in polluted soil regions rather than as an uncontaminated remediation procedure that cannot associate favorably with the expense of alternative technologies [86,87]. Valuable biomass comprises feedstock for pyrolysis, bioenergy, timber biofortified products (enriched in $\mathrm{Fe}, \mathrm{Zn}$, or Se) for dietary supplements, or ecologically significant species. The major risk related to the application of biomass to get energy is the matter of effluence transmission along with heavy metal residue amount in the biomass. Pollutants present in the crop yield may be the origin of complications at higher stages of biofuel generation and the result on whether crop absorption 
should be encouraged. There should be hazard management of agricultural products. Also, the copies can be prepared that inhibit the uptake of harmful impurities by means of excluders as a substitute for hyperaccumulators [88]. Still, there is very little study and awareness about the release, which may be produced for the application of plants as well as the use of wood products for bioenergy. There is a necessity of wider research and study on the acceptance of several crops, burning rests, and emissions, content in biofuel below various situations along with diverse technological procedures to be confident that the output of phytoremediation should be used for bioenergy with negligible ecological effects. The attained information thereafter be connected to regulations plus the standard values, bearing in mind the arrangement of byproducts as well as the remaining products, for example, ash, digestate, and probable exploitation of environmentally safe management [88].

\subsection{Eco-friendly/green technique for metal removal.}

Phytoremediation is regarded as environmentally acceptable, non-invasive, plus worthy of its expense in technology to purify the contaminated soils by harmful metal accumulation. Plants implement various procedures to develop soil contaminated by metal despite its contrary effects on its progression. They eliminate the heavy metals in all the metabolically functional junctions or zones through controlled absorption of metals transfer from root to shoot [89]. Phytoremediation strategies for the decontamination of soils have long been considered more environmentally friendly, less costly, and necessitating lower maintenance than engineeringbased technologies. They can also be applied to large areas. Phytoremediation of $\mathrm{Hg}$ contaminated sites has been aimed at either extracting, stabilizing, or volatilizing the metal. However, several problems need to be overcome for the phytoremediation of $\mathrm{Hg}$-contaminated soils to become a reliable solution. An important impediment is the high mobility of $\mathrm{Hg}$ between the environmental compartments due to its ease of speciation.

Ionic $\mathrm{Hg}$ from the soil is frequently reduced to $\mathrm{Hg} 0$, especially by microorganisms, and then emitted into the air [90]. To afford acceptable to the environment, the necessity of ecologically safe and healthy economy as well as organic agriculture to lift human capability towards an integral, active plus a healthy surrounding. The threat of pollutions is extremely elevated level, hence the application of microbes [91] and plants $[92,93,94]$ to purify the polluted areas provides an admirable solution. Both the use of appropriate photosynthetic bacteria as well as plants can remove the contaminants, for example, dyes, pesticides, heavy metals, crude oil, etc. [91,93]. This method of phytoremediation has become the most valuable method, sustainable techniques for removal along with effective of its expense, sequestration, and/or detoxification of contaminants, for example, metals and metalloids $(\mathrm{Cu}, \mathrm{Hg}, \mathrm{Cd}, \mathrm{As}, \mathrm{Pb}$, $\mathrm{Zn}$, Se, and $\mathrm{Co}$ ) from the ground and aquatic surroundings. Additionally, this plant-based technique encompasses both transgenic plants as well as conventional plant species. The first one is that transgenic plants have grown very popular among scientists due to their exclusive ability to remediate contaminated environs where the failure of conventional plants is evident. The advantages of green technologies, particularly phytoremediation, imitate plants' genetic capability to exclude contaminants from ground soil. The exceptional assets of hyperaccumulator plants show through a collection of innate or foreign/introduced genes [95]. Phytoremediation has gained consideration by the current explode of saving the vulnerable and exhausting environment, as an environmentally acceptable approach, which uses the regular capacities of plants-remediate contaminated environment. Phytoremediation denotes the application of green plants in reducing the harmful effects of probable pollutants present in the 
surroundings. Plants are inimitable creatures, which encompasses exceptional metabolic as well as immersion abilities and conveyance systems that can absorb nutrients plus pollutants specifically from the resources surrounding them. This technique is used for remediation of heavy metals from the ground and found to be financially affordable, also effective in comparison to the engineering methods such as soil incineration, soil washing, flushing, solidification, etc. [96,97,98].
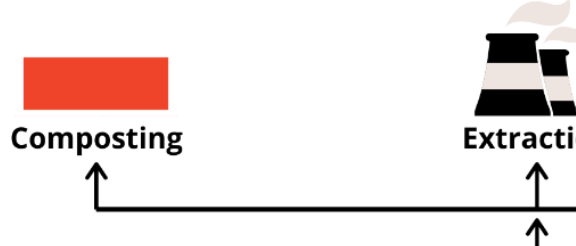

Extraction

action

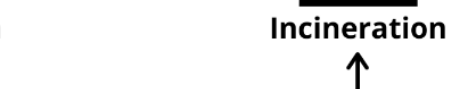

Recovery \& Use

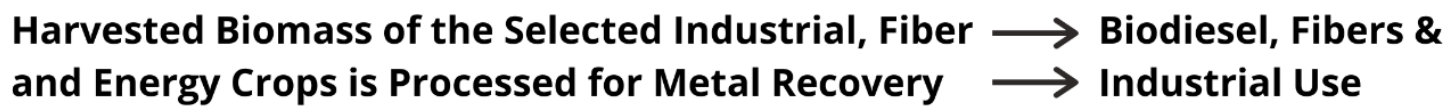

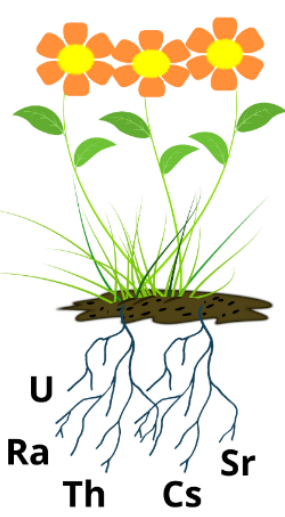

Radionuclides

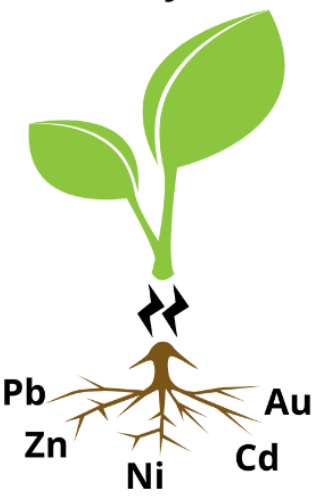

Metals \& Metalloids

\section{Appropriate Agrotechnology is Being Developed via '-omics' \& Biogeotechnology for Sustainable Development}

Figure 4. Phytoremediation as a green technology.

\subsection{Mechanism of phytoremediation for heavy metals.}

We necessitate increasing our understanding of the procedure included in mobilization as well as the transfer of such heavy metals to contaminated soils [99]. Heavy metal stress has an important impact on plants. That's why the plants have to avoid it through some mechanisms such as metal ion adsorbed at the root surface, root cells transversely membrane metals ions help to move into the root cells, in the vacuole, metal ions are immobilized in small proportions, movement of the metal intracellularly through the vascular tissue of root. The accumulation of metallic ions through the root-to-shoot transfer and also from leave tissue.

Mobilization and arrest of heavy metals is an important role of rhizobacteria which provide tolerance to it. Soil contamination is a significant plus a stern environmental problem and causes a negative effect on agriculture and human health [100,101]. The process, which involves the removal of lethal metals by vegetal roots or seedlings, cannot be alike for various metals. Let us take the case of $\mathrm{Pb}$; two main concepts included are exchangeable sorption and precipitation. Examination of $B$. juncea roots bare to $\mathrm{Pb}$ displayed the development of precipitates in the cell wall, which included considerable amounts of $\mathrm{Pb}$ carbonates [102]. On the pathway of metal intake as well as transference, the phytoremediation method is categorized as phytovolatilization (conversion of certain heavy metals into gaseous forms and 
vaporize into the atmosphere through leaves), phytoextraction (uptake of metals from the environment into the plant biomass), phytofiltration (adsorb and/or absorb the metal pollutants from the aqueous environment through plant parts) and phytostabilization (reducing the mobilization of the metal by plant activities) [103].

\subsection{Heavy metals consumption, translocation, and tolerance.}

The roots of plants take heavy metals; these metals are present in soil solution. Plants take heavy metals from soil solution into their roots. Following the arrival of heavy metal ions in the root, they are either stored or translocated to the shoots mostly by the help of xylem vessels, thus occupying the vacuoles. Vacuoles have low metabolic activities and are known to be cellular organelles. Heavy metal sequestration present in the vacuole is either the means to exclude the extra metal ions present in the cytosol, along with some of them decreasing their relations with cellular metabolic processes. Compartmentalization of complexed metals in vacuoles is part of the tolerance mechanism in metal hyperaccumulators [104-110]. The vacuoles are regulated and controlled by molecules variety throughout the translocation of heavy metal in the ground solution. Some molecules are formed during heavy metal cross membranes transfer, and others are included for forming metal complexes. Heavy metal ions uptake depends upon channel proteins, also called special transporters present in the root plasma membrane $[111,112]$.

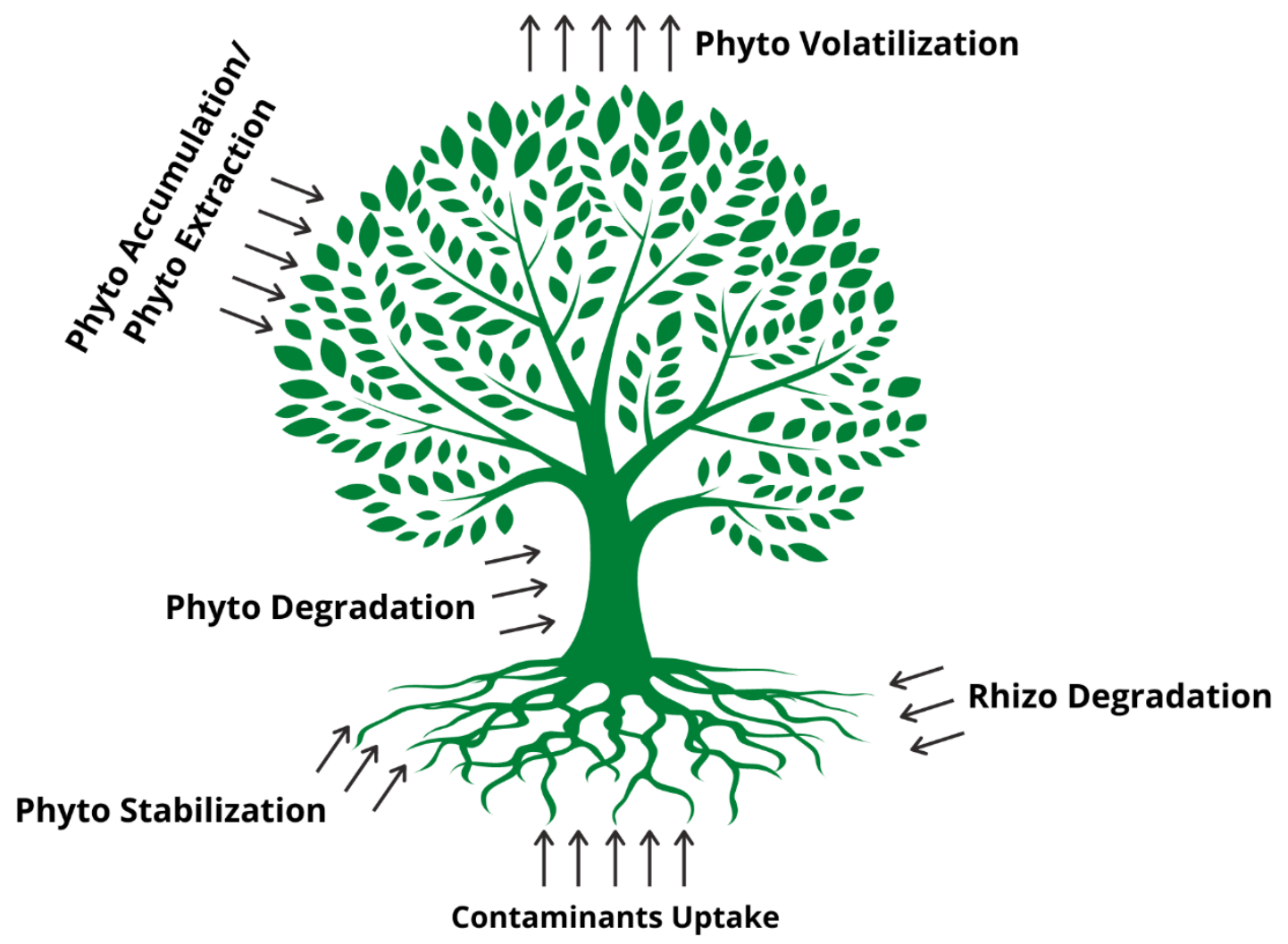

Figure 5. Mechanism of heavy metals uptake through phytoremediation.

Heavy metal tolerance is the major precondition for the positive operation of phytoremediation. Plants are equipped with multiple means of HM detoxification and tolerance. They are equally unique as well as added to variable degrees of detoxification of separate HMs. By these, plants attempt to retain the cellular amounts of HMs under the deadliness threshold stages $[113,114]$. On the other side, tolerance refers to the ability to cope with the concentrated metal ions by means of diverse procedures. The procedures rely on the 
metal included as well as its quantity in soil, developmental stage, plant species, and organs [115]. Apoplastic and symplastic are the two major pathways by which plants consume metal ions via roots. The apoplastic flow in the metal ions is conceivable only as non-cationic metal chelates, as cell walls have relatively great exchange capacity for cations [116].

\subsection{Choosing the conditions of plant species for phytoremediation.}

Choosing an appropriate plant species relies on numerous features like the capacity to deal with the respective pollutants, attain remedial properties, and flexibility to other sitespecific features $[117,118]$. The utmost favored floral traits comprise of the degree of suitability to native climates changes, penetration of respective plant root into the soil, capability of the floral type to flourish in the corresponding soil type, the recognition skill of plant to exclude the impurities to a reduced lethal form, faster progression rate, effortlessness in implanting plus the reduced maintenance cost and the consumption of a greater amount of water through evapotranspiration [119]. The plant species chosen for habituating at the brownfield locations have few maintenance necessities that comprise the occurrence that the plant should be mowed; the need for fertilizer, monitoring programs, harvesting, pruning, and replanting [120].

In choosing a suitable plant species for these early trials, the primary factor was plants of precise concern to the United States Air Force. These involved the four tree species above, tarragon and pickleweed. Two additional tree species, sycamore (Platanus occidentalis) and hackberry (Celtis laevigata), also were of interest to the Air Force for inclusion in these initial experiments. Unluckily, commercially grown seedlings of these varieties were not available at the time of the experiment, and it is reported that these varieties do not easily deviate from the specimens. Seedlings of sycamore, sweetgum, and perhaps even hackberry can be obtained from the Texas Forest Service for about $\$ 20 / 100$, but may require an application a year in advance for seed collection [121]. The high phytoremediation of iron pollutants from the soil requires a variety of plants with high biomass, which grow faster as well as concentrate the metals. The extraction of iron from the tissues of deciduous plants should be much higher than the soil to ensure that the quantity of plant pollutants formed by phytoremediation is less than the initial quantity of polluted soil [122].

\subsection{Metal hyperaccumulators and wetland plants for metal removal}

Approximately few species have the excessive capacity to gather metals in their biomass. Thus they are denoted as "hyperaccumulators". On the other hand, [123] it is found that a large amount of shoot biomass can overcome lower shoot concentration. Also, the plant species appropriate for phytoremediation cannot be restricted to hyperaccumulators. Plants are capable of accumulating heavy metals in aboveground plant parts at concentrations as high as those found in the polluted soil [124]. They come under the broader category of accumulators, which are viewed as special hyperaccumulators. Hyperaccumulators are considered high tolerant against the heavy metal that accumulates in the shoot parts of plants [125]. Scientifically the standard for hyperaccumulators is not well defined. It is used for the phytoremediation of toxic heavy metals and also for the phytomining processes like Pd and $\mathrm{Au}$. The metal accumulation inside the nooks of tissue is grown to produce biomass, which is the amount extracted from hyperaccumulator. Some plants have the natural ability to extract heavy metals from contaminated soils and act as hyperaccumulation [125-128]. 


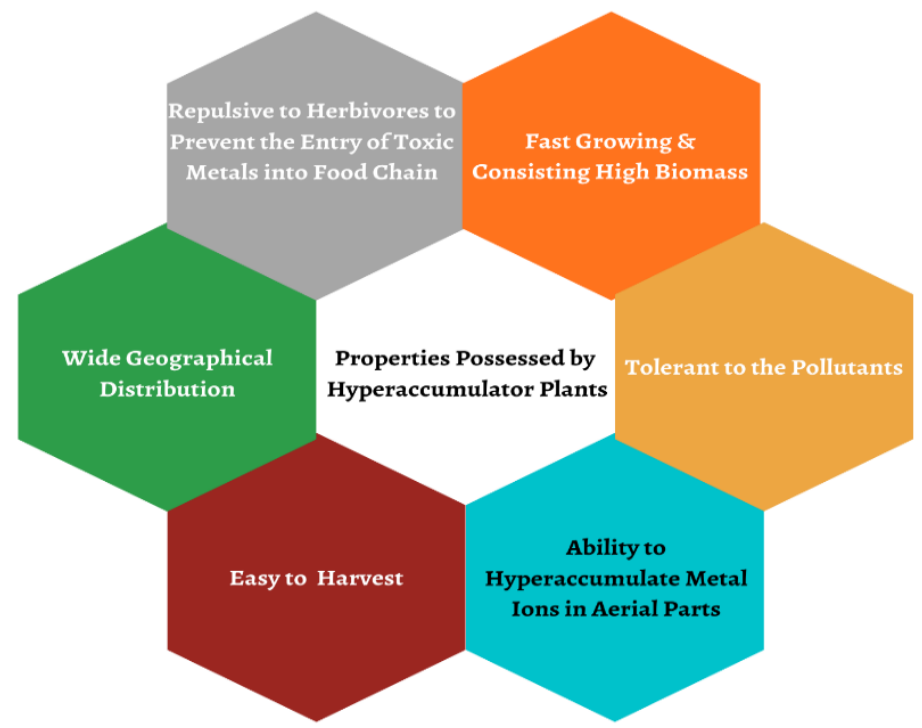

Figure 6. Features to have a plant before getting a hyperaccumulator.

The plant hyperaccumulator can be differentiated from the non-hyperaccumulator by its ability to absorb and gather high concentrations (50-100 times more than non-accumulators) HM ions in its surface tissues without serious impairment to the development of plant plus the significant physiological procedures [129,130]. Hyperaccumulator plants have a different ability to transfer (having translocation factor> 1) high concentrations of toxic iron ions from the roots to shoot the tissue and give them harmless by separating them from the cytoplasm [130].

\subsection{Challenges and phytoremediation limits.}

Even though phytoremediation is a favorable method of soil preparation to deal with heavy metal pollutants, it also suffers to some extent [131]. Longer required cleaning time. The phytoremediation efficacy of many metal hyperaccumulators is frequently restricted due to their reduced growth rate and little biomass. A key task relating to the use of biomass for bioenergy in terms of pollution removal and heavy metal content in biomass has been completed. It applies to areas with little to reasonable levels of metal pollutants as plant development is not supported in highly polluted soils. There is a threat to contamination of the food chain if it is not handled properly and without adequate care [131]. Phytoremediation of diverse kinds of pollutants involves various traits of common plants to function properly. Cautious selection of plant as well as its varieties is important, initially, to guarantee that the plant is adapted to the climate and soil at the appropriate area, secondarily, to activate the phytoremediation of impurities near the surface. Plants that are long-term competitors and survivors under adverse changing conditions often have a chance. Depending on the weather and soil conditions, the plant may need to withstand or tolerate heat, cold, stress, pests, disease, chemicals, and drought to enhance its endurance rate. The category, quantity, and function of exudates plus enzymes created by plant roots will be different among various species even under lesser or more varieties of the same species. A test of 148 phytotoxicity and performance of cultivars/varieties may be required on a specific local basis as a first step in plant selection $[132,133]$.

The concentration of other plants may be impaired and unproductive because of pest infestations as well as disease in tropical and subtropical climates. It is difficult to integrate a tightly bound fraction of metal ions from the soil, e.g., the limited presence of soil impurities. 
One should elude the introduction of offensive plant species such as hyperaccumulators that can affect the diversity of native flowers. Agronomic practices and soil amendments can have a negative impact on pollution flow. Continuous phytoremediation is highly dependent on weather conditions and climate. Phytoremediation is an effective method for areas with little to reasonable levels of metal contamination because of the unsustainable development of the plant is largely polluted soil. Collected metals are transmissible in a food chain in the event of biomass abuse [134]. A key task relating to the use of biomass for bioenergy in terms of pollution removal and heavy metal content in biomass has been completed. Plant contamination can cause problems in the later stages of biofuel production, and the decision on whether plant extraction should be encouraged or not should be made from time to time. There should be risk management of plants or plant selection, and clones can be used to prevent contamination by using non-substitute hyperaccumulators [135]. There is an absence of information about the extraction that can be produced from the use of plants and timber bioenergy materials. More research is needed on biodiversity, fire retardation, and extraction of biofuels under various conditions and technological processes to ensure that the final products of phytoremediation can be used for biological production with minimal environmental impacts. The information obtained thereafter must be consistent with regulatory and regulatory values, as well as the classification of processed and residual products such as ash and digestion and the possible use or management of natural noise. Another significant task is the recent law, along with land reform, is based on a complete focus on soil pollution and not on land use or risk management, which could be a hindrance to us.

\section{Genetically Engineered Plants as Metal Hyperaccumulators}

Genetically modified plants $[137,138]$ can be enhanced through the phytoremediation process. Biomass generation and mineral mining can be enhanced by converting genes into hyper-accumulator plants [138]. Though, the safety and monitoring issues restrict the application of such plants for commercial purposes [140]. Numerous genes are included in metal isolation, logistics plus material transfer, and the transfer of any of these genes to plants that can be registered as a possible plant engineering strategy for features to improve phytoremediation features. Reliant on the plans, transgenic plants can be advanced to achieve higher metal concentrations in harvested parts. Genetic transfer or exposure to genes will result in improved iron intake, transfer, replacement, or intracellular directing. Genetic engineering for the synthesis of metal chelators will improve the plant's ability to acquire iron [141, 142, 143]. The engineering approach has successfully helped to amend the natural functions of plants by modifying primary and secondary metabolism and adding new phenotypic and genotypic traits to plants to understand and improve their phytoremediation properties [144]. Numerous reports have supported the proliferation of valuable natural products with higher manifestations of biosynthetic genes with a strong promoter and signal sequence appropriate to control the formation of cell-cell space [145]. The use of tissue culture to select genes with enhanced biodegradative (natural) or improved genetic engineering, and to regenerate new plant species based on these selected cells of heavy metal in plant populations, provided a chance to examine the initial levels in plant diversity under the pressure of selection and selection of plant phytoremediation as shown in Fig. 7 [146, 147]. 


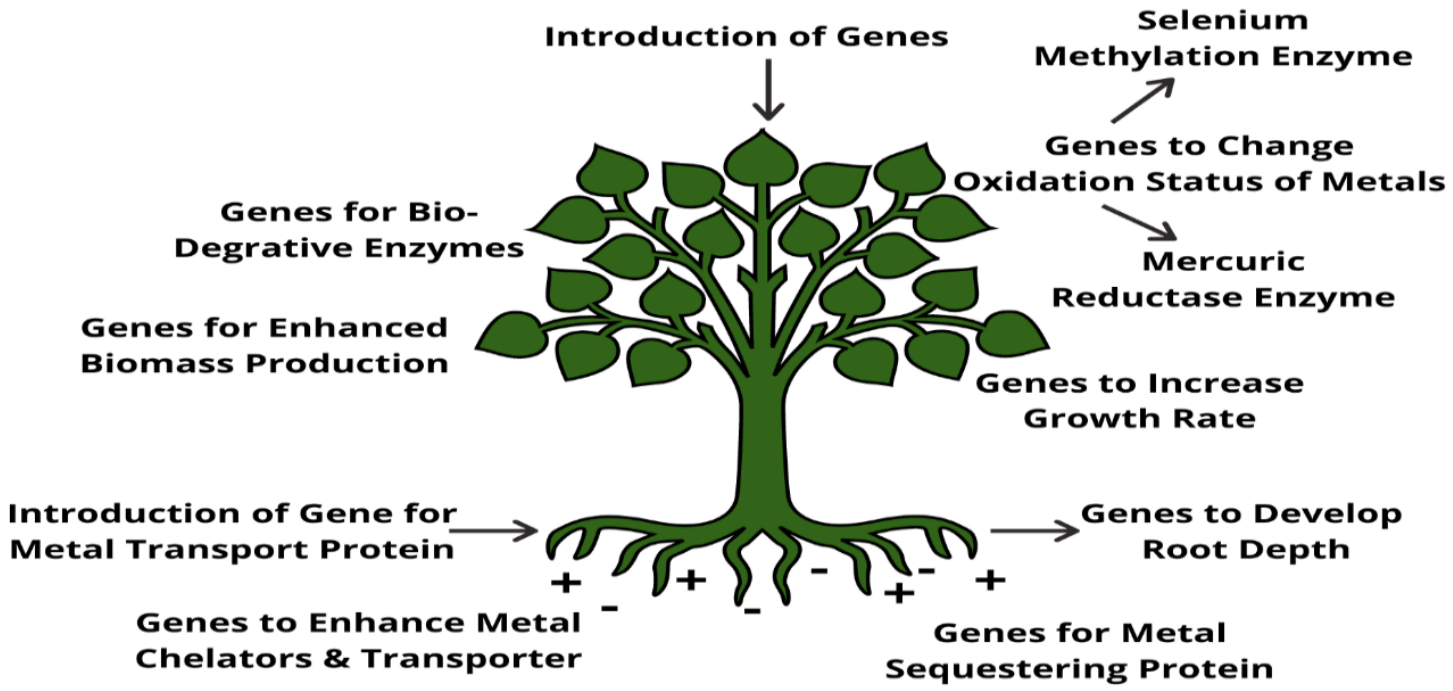

Figure 7. Genetic engineering in phytoremediation.

The existence of heavy metal hyperaccumulator plants has been known for a long, but the idea of cultivating plants to extract soil pollutants (natural phytoextraction) is relatively recent [148]. This technique has numerous limitations that prevent it from decontaminating soils in a short time. However, investigations up until today have had promising results [149] while achieving financial gain. Phytoextraction can be used to a restricted amount of substances liable on the presence of hyperaccumulator plants with appropriate properties.

\section{Nano-phytoremediation: Nanomaterials for phytoremediation}

Nano-phytoremediation includes together nanotechnology as well as phytoremediation to purify the surrounding. Nanomaterials have a large application currently in the departments of painting, cosmetics, textiles, medicines, etc. Nanotechnology enhances phytoremediation competence, plus the nanoparticles are applied for remediation of soils and water polluted with heavy metal, organic, and inorganic pollutants. Current research and studies have explained the reports of organic toxins, for example, molinate, nano-sized zero-valent irons can ruin chlorpyrifos and atrazine. Nanoparticles in enzyme-based bioremediation can be applied in a blend with phytoremediation [150]. Numerous nanomaterials have been established for natural resource application. Nanomaterials are advantageous for the remediation procedure as it has a large surface area. Therefore these materials are highly active than their wholesale form; also, they have the ability to penetrate the polluted areas $[151,152]$ easily.

\subsection{Selection of plants and nanoparticles for nano-phytoremediation.}

Nanoparticles suitable for phytoremediation should have the following characteristics: Nanoparticles must be harmless to the plant. Seedling growth, root expansion, crop height, and biomass are all examples of growth. Plants produce a significant amount of phytoenzymes. Having the potential to create plant growth hormones, The ability to bind pollutants and improve the availability of plants Process of phytoremediation has been improved. The potential use of a combination of nano- and phytoremediation (phyto-nano-treatment) can be used effectively to repair contaminated soils. Nano-phytoremediation (nanoparticle- and plantbased technologies) uses naturally occurring or genetically modified plants assisted by nanomaterials/nanoparticles to clean up contaminated areas. The use of selected nanoparticles has led to significantly improved plant growth, and nano-augmentation has increased the 
phytoremediation potential leading to greater removal of contaminants from the soil environment. Many nanoparticles have been identified as the catalyst for plant growth because they promote plant growth hormones and better absorb pollutants by plant species. Various plant species have been found to increase growth from neglected treatment processes. Several studies have also confirmed the positive effects of iron and metal oxide nanoparticles on high plant growth. In addition to the benefits of nanocarbon, the biggest challenge to its use in soil preparation is its potential toxicity to plant and bacterial soils [153]. Nano-phytoremediation strategy generally employs the natural plant species aided with nanoparticles for remediation of polluted environments. The incorporation of NMs in the process of phytoremediation technique encompasses a significant footstep in the advancement of ground soil remediation. Numerous studies have confirmed that different NMs extensively remediate the environment's organic, inorganic, and heavy metal contaminants. The implication of certain NMs has led to enhanced development of plants and enlarged the phytoremediation process of contaminants from the environment. Many nanoparticles promoted plant development because of their capability in increasing plant growth hormones and healthier intake of pollutants via the species [154]. There are numerous reports present in the literature that showed the utility of plants for the elimination of diverse contaminants at polluted locations [155-160].

\subsection{Heavy metal nano-phytoremediation: application and implications}

Nanoremediation uses of nanomaterials in environmental remediation is a lucrative and emerging concept which ecologically acceptable. Nanoparticles (NPs) are highly effective for environmental remediation. Application of NPs in remediating polluted environment is an in effective technique when related to the application of old-style alterations because of minor size, large precise exterior, and the reactivity of NPs. The application of nanoparticles in the panorama of environmental remediation of contaminated soil and water has gained huge consideration in the recent era. The use of a reasonable and environmentally safe amendment for contamination cleanup has gotten a lot of attention and care, at least at first, because of its likely positive activity and reduced hazardous behavior. Nanoparticles have the potential to boost up remediation process in terms of nanofertilizers, as well as other nonmaterial-based formulations. The response of the NPs in the environment can be extremely intricate and diverse, depending on a variety of constraints. In recent years, different varieties of NPs such as silver nanoparticles, nano-fibers, carbon nanotubes, nanoscale zero-valent iron, etc., have been used to remediation of different kinds of pollutants comprised of chlorinated compounds, organic compounds, heavy metals, and hydrocarbons. NPs based remediation strategy can worthy of its implementation and investment cost as well as the in situ sanitary measures aimed at remediation of contaminants from the environment [154]. Though plants may discharge out harmful materials, there is a chance of minute materials entering our food chain via such a plant uptake procedure. The gigantic task facing is nano-phytoremediation process is how to dispose of the accumulated heavy metals in plants, as they are considered toxic wastes [161]. A recent study of the usage of nanotechnology in controlling the ecological toxic waste chiefly focuses on the formation of fresh resources and application of such tools and techniques; to the environment is the crossing point procedure, etc. Their use in the restoration of polluted soil is the major initiative $[162,163]$.

\section{Conclusion and Future Prospects}


The deadly effect of heavy metals has increased global consideration, improving appropriate resolution for eliminating such harmful contaminants from the environment. The heavy metal can go into the life system of living being frequently due to the consumption of polluted water and eating stuff, which may cause severe diseases to the humans. Nowadays, the supreme of the work is incomplete up to research laboratory, and glasshouse only rare studies have been done to assess the phytoremediation efficacy in the genuine arena. To comprehend the mechanism which improves the efficacy of phytoremediation to distinguish molecular developments and accomplishments. Commercially practicable technology for remediation of heavy metal and phytomining of heavy metals by phytoextraction. Research is still growing to detect hyperaccumulation coding genetic factors for specific heavy metals buried inside the beds and mixed with water and occupied into the soil in our environment.

\section{Funding}

This review received no external funding.

\section{Acknowledgments}

This review has no acknowledgment.

\section{Conflicts of Interest}

The authors declare no conflict of interest.

\section{References}

1. Khan, S.; Hesham, A.E.; Qiao, M.; Rehman, S.; He, J.Z. Effects of Cd and Pb on soil microbial community structure and activities. Environmental Science and Pollution Research 2010, 17, 288-96, https://doi.org/10.1007/s11356-009-0134-4.

2. Salt, D.E.; Blaylock, M.; Kumar, N.P.; Dushenkov, V.; Ensley, BD.; Chet, I.; Raskin, I. Phytoremediation: a novel strategy for the removal of toxic metals from the environment using plants. Bio/technology 1995, 13, 468-74.

3. Raskin, I.; Kumar, PN.; Dushenkov, S.; Salt, DE. Bioconcentration of heavy metals by plants. Current Opinion in biotechnology 1994, 1, 5, 285-90, https://doi.org/10.1016/0958-1669(94)90030-2.

4. Cunningham, S.D.; Berti, W.R.; Huang, J.W. Phytoremediation of contaminated soils. Trends in Biotechnology 1995, 13, 393-397,https://doi.org/10.1016/S0167-7799(00)88987-8.

5. Cunningham, S.D.; Ow, D.W. Promises and Prospects of Phytoremediation. Plant Physiology 1996, 110, 715-719, https://doi.org/10.1104/pp.110.3.715.

6. Sirko, A.; Brodzik, R. Plant ureases: roles and regulation. Acta Biochimica Polonica 2000, 31, 47, 1189-95, https://doi.org/10.18388/abp.2000_3972.

7. Ochiai, E.I. Bioinorganic chemistry: An introduction. Allyn and Bacon, Boston 1977, 218-262.

8. Seth, C.S.; Kumar Chaturvedi, P.; Misra, V. The role of phytochelatins and antioxidants in tolerance to Cd accumulation in Brassica juncea L. Ecotoxicology and Environmental Safety 2008, 71, 76-85, https://doi.org/10.1016/j.ecoenv.2007.10.030.

9. Vangronsveld, J.; Clijsters, H. Toxic effects of metals. Plants and the chemical elements: biochemistry, uptake, tolerance and toxicity. 1994, 30, 149-77, https://doi.org/10.1002/9783527615919.

10. Shaw, BP.; Sahu, SK.; Mishra, RK. Heavy metal induced oxidative damage in terrestrial plants. InHeavy metal stress in plants. Springer, Berlin, Heidelberg, 2004, 84-126, https://doi.org/10.1007/978-3-66207743-6_4.

11. Göhre, V.; Paszkowski, U. Contribution of the arbuscular mycorrhizal symbiosis to heavy metal phytoremediation. Planta 2006, 223, 1115-22. 
12. Nyarko, B.J.; Dampare, S.B.; Serfor-Armah, Y.; Osae, S.; Adotey, D.; Adomako, D. Biomonitoring in the forest zone of Ghana: the primary results obtained using neutron activation analysis and lichens. International Journal of Environment and Pollution 2008, 1, 32, 467-76, https://doi.org/10.1504/IJEP.2008.01841.

13. Kim, K.-H.; Ebinghaus, R.; Schroeder, W.H.; Blanchard, P.; Kock, H.H.; Steffen, A.; Froude, F.A.; Kim, M.Y.; Hong, S.; Kim, J.-H. Atmospheric Mercury Concentrations from Several Observatory Sites in the Northern Hemisphere. Journal of Atmospheric Chemistry 2005, 50, 1-24, https://doi.org/10.1007/s10874005-9222-0.

14. Ahluwalia, S.S.; Goyal, D. Microbial and plant derived biomass for removal of heavy metals from wastewater. Bioresource Technology 2007, 98, 2243-2257, https://doi.org/10.1016/j.biortech.2005.12.006.

15. Kumar, P.; Deep, A.; Kim, KH.; Brown, RJ. Coordination polymers: opportunities and challenges for monitoring volatile organic compounds. Progress in Polymer Science 2015, 1, 102-18, https://doi.org/10.1016/j.progpolymsci.2015.01.002.

16. Yoon, J.; Cao, X.; Zhou, Q.; Ma, LQ. Accumulation of $\mathrm{Pb}, \mathrm{Cu}$, and $\mathrm{Zn}$ in native plants growing on a contaminated Florida site. Science of the total environment 2006, 15, 368, 456-64, https://doi.org/10.1016/j.biortech.2005.12.006.

17. Jamali, M.K.; Kazi, T.G.; Arain, M.B.; Afridi, H.I.; Jalbani, N.; Kandhro, G.A.; Shah, A.Q.; Baig, J.A. Heavy metal accumulation in different varieties of wheat (Triticum aestivum L.) grown in soil amended with domestic sewage sludge. Journal of Hazardous Materials 2009, 164, 1386-1391, https://doi.org/10.1016/j.jhazmat.2008.09.056.

18. Ekmekyapar, F.; Sabudak, T.; Seren, G. Assessment of heavy metal contamination in soil and wheat (Triticum aestivum L.) plant around the Çorlu-Çerkezkoy highway in Thrace region. Global NEST Journal 2012, 14, 496-504.

19. Srivastav, AL.; Kaur, T.; Rani, L.; Kumar, A. Scientific research production of India and China in environmental chemistry: a bibliometric assessment. International Journal of Environmental Science and Technology 2019, 16, 4989-96, https://doi.org/10.1007/s13762-019-02306-6.

20. Chowdhury, S.; Mazumder, MJ.; Al-Attas, O.; Husain, T. Heavy metals in drinking water: occurrences, implications, and future needs in developing countries. Science of the total Environment. 2016, 569, 476-88, https://doi.org/10.1016/j.scitotenv.2016.06.166.

21. Kim, S.; Park, C.M.; Jang, M.; Son, A.; Her, N.; Yu, M.; Snyder, S.; Kim, D.-H.; Yoon, Y. Aqueous removal of inorganic and organic contaminants by graphene-based nanoadsorbents: A review. Chemosphere 2018, 212, 1104-1124,https://doi.org/10.1016/j.chemosphere.2018.09.033.

22. Khanam, R.; Kumar, A.; Nayak, A.K.; Shahid, M.; Tripathi, R.; Vijayakumar, S.; Bhaduri, D.; Kumar, U.; Mohanty, S.; Panneerselvam, P.; et al. Metal(loid)s (As, $\mathrm{Hg}, \mathrm{Se}, \mathrm{Pb}$ and $\mathrm{Cd}$ ) in paddy soil: Bioavailability and potential risk to human health. Science of The Total Environment 2020, 699, 134330, https://doi.org/10.1016/j.scitotenv.2019.134330

23. Srivastav, A.L. Development of inorganic adsorptive media for the removal of nitrate and fluoride from water (Doctoral dissertation, Ph.D. Thesis, Indian Institute of Technology (BHU) Varanasi (India) 2013.

24. Ranjan, M.; Singh, P.K.; Srivastav, A.L. A review of bismuth-based sorptive materials for the removal of major contaminants from drinking water. Environmental Science and Pollution Research. 2020, 27, 17492504, https://doi.org/10.1007/s11356-019-05359-9.

25. Azizullah, A.; Khattak, MN.; Richter, P.; Häder, DP. Water pollution in Pakistan and its impact on public health - a review. Environment international 2011, 37, 479-97, https://doi.org/10.1016/j.envint.2010.10.007

26. Khan, M.S.; Zaidi, A.; Wani, P.A.; Oves, M. Role of plant growth promoting rhizobacteria in the remediation of metal contaminated soils. Environmental Chemistry Letters 2009, 7, 1-19, https://doi.org/10.1007/s10311008-0155-0.

27. Mariyam, Z.; Bushra, T.; Qurban, A.; Muhamad, T.; Hina, Z.; Nasir, I.A.; Waheed, A.; Mujtaba, B. Role of PGPR to improve potential growth of tomato under saline condition: an overview. Life Science Journal 2015, 12, 54-62.

28. Quartacci, M.F.; Argilla, A.; Baker, A.J.M.; Navari-Izzo, F. Phytoextraction of metals from a multiply contaminated soil by Indian mustard. Chemosphere 2006, 63, 918-925, https://doi.org/10.1016/j.chemosphere.2005.09.051

29. Lim, H.-S.; Lee, J.-S.; Chon, H.-T.; Sager, M. Heavy metal contamination and health risk assessment in the vicinity of the abandoned Songcheon $\mathrm{Au}-\mathrm{Ag}$ mine in Korea. Journal of Geochemical Exploration 2008, 96, 223-230, https://doi.org/10.1016/j.gexplo.2007.04.008. 
30. Mehta, J.; Bhardwaj, S.K.; Bhardwaj, N.; Paul, A.K.; Kumar, P.; Kim, K.-H.; Deep, A. Progress in the biosensing techniques for trace-level heavy metals. Biotechnology Advances 2016, 34, 47-60, https://doi.org/10.1016/j.biotechadv.2015.12.001.

31. Hamilton, J.W.; Kaltreider, R.C.; Bajenova, O.V.; Ihnat, M.A.; McCaffrey, J.; Turpie, B.W.; Rowell, E.E.; Oh, J.; Nemeth, M.J.; Pesce, C.A.; Lariviere, J.P. Molecular basis for effects of carcinogenic heavy metals on inducible gene expression. Environmental Health Perspectives 1998, 106, 1005-15, https://doi.org/10.1289/ehp.98106s41005.

32. Aragay, G.; Pons, J.; Merkoçi, A. Recent Trends in Macro-, Micro-, and Nanomaterial-Based Tools and Strategies for Heavy-Metal Detection. Chemical Reviews 2011, 111, 3433-3458, https://doi.org/10.1021/cr100383r

33. Chaney, R.L. Plant uptake of inorganic waste constituents. In: Parr, J.F.E.A. (Ed.), Land Treatment of Hazardous Wastes. Noyes Data Corp., Park Ridge 1993, 50-76.

34. Garbisu, C.; Alkorta, I. Basic concepts on heavy metal soil bioremediation. European Journal of Mineral Processing and Environmental Protection 2003, 1, 3, 58-66.

35. Van Aken, B. Transgenic plants for enhanced phytoremediation of toxic explosives. Current Opinion in Biotechnology 2009, 1, 20, 231-6, https://doi.org/10.1016/j.copbio.2009.01.011.

36. Prasad, MN. Phytoremediation of metal-polluted ecosystems: hype for commercialization. Russian Journal of Plant Physiology 2003, 50, 686-701, https://doi.org/10.1023/A:1025604627496.

37. Chaudhry, T.M.; Hayes, W.J.; Khan, A.G.; Khoo, C.S. Phytoremediation-focusing on accumulator plants that remediate metal-contaminated soils. Aust. J. Ecotoxicol 1998, 4, 37-51.

38. Vangronsveld, J.; Herzig, R.; Weyens, N.; Boulet, J.; Adriaensen, K.; Ruttens, A.; Thewys, T.; Vassilev, A.; Meers, E.; Nehnevajova, E.; van der Lelie, D. Phytoremediation of contaminated soils and groundwater: lessons from the field. Environmental Science and Pollution Research 2009, 16, 765-94.

39. Aken, BV.; Correa, PA.; Schnoor, JL. Phytoremediation of polychlorinated biphenyls: new trends and promises. Environmental science \& technology 2010, 44, 2767-76, https://doi.org/10.1021/es902514d.

40. Wuana, R.A.; Okieimen, F.E. Heavy metals in contaminated soils: a review of sources, chemistry, risks and best available strategies for remediation. International Scholarly Research Notices 2011, https://doi.org/10.5402/2011/402647.

41. Jacob, J.M.; Karthik, C.; Saratale, R.G.; Kumar, S.S.; Prabakar, D.; Kadirvelu, K.; Pugazhendhi, A. Biological approaches to tackle heavy metal pollution: a survey of literature. Journal of environmental management 2018, 217, 56-70, https://doi.org/10.1016/j.jenvman.2018.03.077.

42. Ali, H.; Khan, E.; Sajad, MA. Phytoremediation of heavy metals - concepts and applications. Chemosphere. 2013, 91, 869-81, https://doi.org/10.1016/j.chemosphere.2013.01.075.

43. Adriano, DC.; Wenzel, WW.; Vangronsveld, J.; Bolan, NS. Role of assisted natural remediation in environmental cleanup. Geoderma. 2004, 1, 122, 121-42, https://doi.org/10.1016/j.geoderma.2004.01.003.

44. Pandey, V.C.; Pandey, D.N.; Singh, N. Sustainable phytoremediation based on naturally colonizing and economically valuable plants. Journal of cleaner Production 2015, 86, 37-9, https://doi.org/10.1016/j.jclepro.2014.08.030.

45. Sharma, P.; Pandey, S. Status of phytoremediation in world scenario. International Journal of Environmental Bioremediation \& Biodegradation 2014, 2, 178-91, https://doi.org/10.12691/ijebb-2-4-5.

46. Ebbs, S.D.; Bradfield, S.J.; Kumar, P.; White, J.C.; Musante, C.; Ma, X. Accumulation of zinc, copper, or cerium in carrot (Daucus carota) exposed to metal oxide nanoparticles and metal ions. Environmental Science: Nano. 2016, 3, 114-26, https://doi.org/10.1039/C5EN00161G.

47. Lado, L.R.; Hengl, T.; Reuter, H.I. Heavy metals in European soils: a geostatistical analysis of the FOREGS Geochemical database. Geoderma 2008, 148, 189-99, https://doi.org/10.1016/j.geoderma.2008.09.020.

48. Kumar, S.S.; Celin, S.M.; Bishnoi, N.R.; Malyan, S.K. Phytoremediation of HMX contaminated soil through Jatropha curcas. International Journal of Recent Scientific Research Research 2014, 5, 1444-50.

49. Micó, C.; Recatalá, L.; Peris, M.; Sánchez, J. Assessing heavy metal sources in agricultural soils of an European Mediterranean area by multivariate analysis. Chemosphere 2006, 65, 863-72, https://doi.org/10.1016/j.chemosphere.2006.03.016.

50. Wongsasuluk, P.; Chotpantarat, S.; Siriwong, W.; Robson, M. Heavy metal contamination and human health risk assessment in drinking water from shallow groundwater wells in an agricultural area in Ubon Ratchathani province, Thailand. Environmental geochemistry and health 2014, 36, 169-82. 
51. Caravanos, J.; Carrelli, J.; Dowling, R.; Pavilonis, B.; Ericson, B.; Fuller, R. Burden of disease resulting from lead exposure at toxic waste sites in Argentina, Mexico and Uruguay. Environmental Health. 2016, 15, 1-9, https://doi.org/10.1186/s12940-016-0151-y.

52. Connor, R.; Renata, A.; Ortigara, C.; Koncagül, E.; Uhlenbrook, S.; Lamizana-Diallo, BM.; Zadeh, SM.; Qadir, M.; Kjellén, M.; Sjödin, J.; Hendry, S. The united nations world water development report 2017. wastewater: the untapped resource. The United Nations World Water Development Report 2017.

53. Prusty, B.G.; Sahu, K.C.; Godgul, G. Metal contamination due to mining and milling activities at the Zawar zinc mine, Rajasthan, India: 1. Contamination of stream sediments. Chemical Geology 1994, 112, 275-91, https://doi.org/10.1016/0009-2541(94)90029-9.

54. Dietz, R.; Outridge, PM.; Hobson, KA. Anthropogenic contributions to mercury levels in present-day Arctic animals-a review. Science of the Total Environment 2009, 407, 6120-31, https://doi.org/10.1016/j.scitotenv.2009.08.036.

55. Wang, Q.; Kim, D.; Dionysiou, D.D.; Sorial, G.A.; Timberlake, D. Sources and remediation for mercury contamination in aquatic systems - a literature review. Environmental pollution 2004, 131, 323-36, https://doi.org/10.1016/j.envpol.2004.01.010.

56. Pratas, J.; Paulo, C.; Favas, P.J.; Venkatachalam, P. Potential of aquatic plants for phytofiltration of uraniumcontaminated waters in laboratory conditions. Ecological Engineering 2014, 69, 170-6, https://doi.org/10.1016/j.ecoleng.2014.03.046.

57. Yadav, H.; Kumar, R.; Sankhla, M. S. Residues of Pesticides and Heavy Metals in Crops Resulting in Toxic Effects on Living Organism. Journal of Seybold Report 2020, 15, 1527-1541.

58. Guittonny-Philippe, A.; Petit, M.E.; Masotti, V.; Monnier, Y.; Malleret, L.; Coulomb, B.; Combroux, I.; Baumberger, T.; Viglione, J.; Laffont-Schwob, I. Selection of wild macrophytes for use in constructed wetlands for phytoremediation of contaminant mixtures. Journal of Environmental Management 2015, 1, 108-23, https://doi.org/10.1016/j.jenvman.2014.09.009.

59. Gorito, A.M.; Ribeiro, A.R.; Almeida, C.M.R.; Silva, A.M. A review on the application of constructed wetlands for the removal of priority substances and contaminants of emerging concern listed in recently launched EU legislation. Environ. Pollut. 2017, 227, 428-443, https://doi.org/10.1016/j.envpol.2017.04.060.

60. Mesa, J.; Mateos-Naranjo, E.; Caviedes, M.; Redondo-Gómez, S.; Pajuelo, E.; Rodríguez-Llorente, I. Scouting contaminated estuaries: Heavy metal resistant and plant growth promoting rhizobacteria in the native metal rhizoaccumulator Spartina maritima. Mar. Pollut. Bull 2015, 90, 150-15, https://doi.org/10.1016/j.marpolbul.2014.11.002

61. Galal, T.M.; Eid, E.M.; Dakhil, M.A.; Hassan, L.M. Bioaccumulation and rhizofiltration potential of Pistia stratiotes L. for mitigating water pollution in the Egyptian wetlands. Int. J. Phytoremediat 2018, 20, 440447, https://doi.org/10.1080/15226514.2017.1365343.

62. Fritio, A.; Greger, M. Aquatic and terrestrial plant species with potential to remove heavy metals from stormwater. Int. J. Phytoremediat 2003, 5, 211-224.

63. Al-Alawy, A.F.; Salih, M.H. Comparative Study between Nanofiltration and Reverse Osmosis Membranes for the Removal of Heavy Metals from Electroplating Wastewater. J. Eng. 2017, 23, 1-21.

64. Levchuk, I.; Màrquez, J.J.R.; Sillanpää, M. Removal of natural organic matter (NOM) from water by ion exchange-A review. Chemosphere 2018, 192, 90-104, https://doi.org/10.1016/j.chemosphere.2017.10.101.

65. Huang, H.; Liu, J.; Zhang, P.; Zhang, D.; Gao, F. Investigation on the simultaneous removal of fluoride, ammonia nitrogen and phosphate from semiconductor wastewater using chemical precipitation. Chem. Eng. J. 2017, 307, 696-706, https://doi.org/10.1016/j.cej.2016.08.134.

66. Burakov, A.E.; Galunin, E.V.; Burakova, I.V.; Kucherova, A.E.; Agarwal, S.; Tkachev, A.G.; Gupta, V.K. Adsorption of heavy metals on conventional and nanostructured materials for wastewater treatment purposes: A review. Ecotoxicol. Environ. Saf. 2018, 148, 702-712, https://doi.org/10.1016/j.ecoenv.2017.11.034.

67. Kulkarni, P.; Olson, N.D.; Paulson, J.N.; Pop, M.; Maddox, C.; Claye, E.; Mongodin, E.F. Conventional wastewater treatment and reuse site practices modify bacterial community structure but do not eliminate some opportunistic pathogens in reclaimed water. Sci. Total Environ. 2018, 639, 1126-1137, https://doi.org/10.1016/j.scitotenv.2018.05.178.

68. Olguín, E.J.; Sánchez-Galván, G. Heavy metal removal in phytofiltration and phycoremediation: The need to di_erentiate between bioadsorption and bioaccumulation. New Biotechnol. 2012, 30, 3-8, https://doi.org/10.1016/j.nbt.2012.05.020.

69. Grandclément, C.; Seyssiecq, I.; Piram, A.; Wong-Wah-Chung, P.; Vanot, G.; Tiliacos, N.; Doumenq, P. From the conventional biological wastewater treatment to hybrid processes, the evaluation of organic 
micropollutant removal: A review. Water Res. 2017, 111, 297-317, https://doi.org/10.1016/j.watres.2017.01.005.

70. González-González, A.; Cuadros, F.; Ruiz-Celma, A.; López-Rodríguez, F. Influence of heavy metals in the biomethanation of slaughterhouse waste. J. Clean. Prod. 2014, 65, 473-478, https://doi.org/10.1016/j.jclepro.2013.07.021

71. Verma, R.K.; Sankhla, M.S.; Kumar, R. Mercury Contamination in Water \& Its Impact on Public Health. International Journal of Forensic Science 2018, 1, 72-78.

72. Sharma, P.; Pandey, AK.; Udayan, A.; Kumar, S. Role of microbial community and metal-binding proteins in phytoremediation of heavy metals from industrial wastewater. Bioresource Technology, 2021, 22, 124750, https://doi.org/10.1016/j.biortech.2021.124750.

73. Tchounwou, P.B.; Yedjou, C.G.; Patlolla, A.K.; Sutton, D.J. Heavy metal toxicity and the environment. Molecular, clinical and environmental toxicology 2012, 133-64, https://doi.org/10.1007/978-3-7643-83404_6.

74. Ma, Y.; Prasad, M.N.; Rajkumar, M.; Freitas, H. Plant growth promoting rhizobacteria and endophytes accelerate phytoremediation of metalliferous soils. Biotechnology advances 2011, 29, 248-58, https://doi.org/10.1016/j.biotechadv.2010.12.001.

75. Awa, S.H.; Hadibarata, T. Removal of heavy metals in contaminated soil by phytoremediation mechanism: a review. Water, Air, \& Soil Pollution. 2020, 231, 1-5, https://doi.org/10.1007/s11270-020-4426-0.

76. Tangahu, B.V.; Sheikh Abdullah, S.R.; Basri, H.; Idris, M.; Anuar, N.; Mukhlisin, M. A review on heavy metals $(\mathrm{As}, \mathrm{Pb}$, and $\mathrm{Hg}$ ) uptake by plants through phytoremediation. International Journal of Chemical Engineering 2011, 1, https://doi.org/10.1155/2011/939161.

77. Rakhshaee, R.; Giahi, M.; Pourahmad, A. Studying effect of cell wall's carboxyl-carboxylate ratio change of Lemna minor to remove heavy metals from aqueous solution. Journal of Hazardous Materials 2009, 163, 165-73, https://doi.org/10.1016/j.jhazmat.2008.06.074

78. Karami, A.; Shamsuddin, Z.H. Phytoremediation of heavy metals with several efficiency enhancer methods. Afr. J. Biotechnol 2010, 9, 3689-3698.

79. Salt, D.E.; Rauser, W.E. MgATP-dependent transport of phytochelatins across the tonoplast of oat roots. Plant Physiology 1995, 107, 1293-301, https://doi.org/10.1104/pp.107.4.1293.

80. Sarwar, N.; Malhi, S.S.; Zia, M.H.; Naeem, A.; Bibi, S.; Farid, G. Role of mineral nutrition in minimizing cadmium accumulation by plants. Journal of the Science of Food and Agriculture 2010, 90, 925-37, https://doi.org/10.1002/jsfa.3916.

81. Sarwar, N.; Bibi, S.; Ahmad, M.; Ok, Y.S. Effectiveness of zinc application to minimize cadmium toxicity and accumulation in wheat (Triticum aestivum L.). Environmental earth sciences 2014, 71, 1663-72, https://doi.org/10.1007/s12665-013-2570-1.

82. Singh Sankhla, M.; Kumar, R.; Prasad, L. Seasonal Variations of Lead and Chromium Concentrations in the Water Samples From Yamuna River in Delhi, India. Iranian Journal of Toxicology 2021, 15, 109-14, http://dx.doi.org/10.32598/ijt.15.2.769.1.

83. Cunningham, SD.; Berti, WR.; Huang, JW. Phytoremediation of contaminated soils. Trends in biotechnology 1995, 13, 393-7, https://doi.org/10.1016/S0167-7799(00)88987-8.

84. Vangronsveld, J.; Herzig, R.; Weyens, N.; Boulet, J.; Adriaensen, K.; Ruttens, A.; Thewys, T.; Vassilev, A.; Meers, E.; Nehnevajova, E.; van der Lelie, D. Phytoremediation of contaminated soils and groundwater: lessons from the field. Environmental Science and Pollution Research. 2009, 16, 765-94, https://doi.org/10.1007/s11356-009-0213-6.

85. Hamby, D.M. Site remediation techniques supporting environmental restoration activities - a review. Science of the Total Environment, 1996, 2, https://doi.org/10.1016/S0048-9697(96)05264-3.

86. Van Der Lelie, D.; Schwitzguébel, JP.; Glass, DJ.; Vangronsveld, J.; Baker, A. Assessing phytoremediation's progress in the United States and Europe. Environmental science \& technology 2001, 35, 446A-52A.

87. Conesa, H.M.; Evangelou, M.W.; Robinson, B.H.; Schulin, R. A critical view of current state of phytotechnologies to remediate soils: still a promising tool?. The Scientific World Journal 2012, 1, https://doi.org/10.1100/2012/173829.

88. Bardos, R.P.; Bone, B.; Andersson-Sköld, Y.; Suer, P.; Track, T.; Wagelmans, M. Crop-based systems for sustainable risk-based land management for economically marginal damaged land. Remediation Journal 2011, 21, 11-33.

89. Kupper, H.; Jie Zhao, F.; McGrath, S.P. Cellular compartmentation of zinc in leaves of the hyperaccumulator Thlaspi caerulescens. Plant physiology 1999, 119, 305-12. 
90. Tiodar, E.D.; Văcar, C.L.; Podar, D. Phytoremediation and microorganisms-assisted phytoremediation of mercury-contaminated soils: Challenges and perspectives. International Journal of Environmental Research and Public Health 2021, 18, 2435.

91. Idi, A.; Nor, M.H.; Wahab, M.F.; Ibrahim, Z. Photosynthetic bacteria: an eco-friendly and cheap tool for bioremediation. Reviews in Environmental Science and Bio/Technology 2015, 14, 271-85, https://doi.org/10.1007/s11157-014-9355-1.

92. Rungwa, S.; Arpa, G.; Sakulas, H.; Harakuwe, A.; Timi, D. Phytoremediation-an eco-friendly and sustainable method of heavy metal removal from closed mine environments in Papua New Guinea. Procedia Earth and Planetary Science 2013, 1, 269-77, https://doi.org/10.1016/j.proeps.2013.01.036.

93. Nikolić, M.; Stevović, S. Family Asteraceae as a sustainable planning tool in phytoremediation and its relevance in urban areas. Urban Forestry \& Urban Greening 2015, 14, 782-9, https://doi.org/10.1016/j.ufug.2015.08.002.

94. Nikolic, M.; Tomasevic, V. Implication of the plant species belonging to Brassicaceae family in metabolization of heavy metal pollutants in urban settings. Polish Journal of environmental studies 2020, 30, 523-534.

95. Ćalasan, V.; Slavković, R.; Rajković, J. Application of green tools in green marketing. Serbian Journal of Engineering Management 2021, 6, 72-7, https://doi.org/10.5937/SJEM2101073C.

96. Sankhla, MS.; Kumari, M.; Nandan, M.; Kumar, R.; Agrawal, P. Heavy metals contamination in water and their hazardous effect on human health-a review. Int. J. Curr. Microbiol. App. Sci 2016, 5, 759-66. http://dx.doi.org/10.20546/ijcmas.2016.510.082.

97. Wang, HQ.; Zhao, Q.; Zeng, DH.; Hu, YL.; Yu, ZY. Remediation of a magnesium-contaminated soil by chemical amendments and leaching. Land Degradation \& Development 2015, 26, 613-9, https://doi.org/10.1002/ldr.2362.

98. Kurade, M.B.; Ha, Y.H.; Xiong, J.Q.; Govindwar, S.P.; Jang, M.; Jeon, B.H. Phytoremediation as a green biotechnology tool for emerging environmental pollution: A step forward towards sustainable rehabilitation of the environment. Chemical Engineering Journal 2021, 19, https://doi.org/10.1016/j.cej.2021.129040.

99. Antoun, H. Plant-growth-promoting rhizobacteria. Brenner's Encyclopedia of Genetics, 2nd edition, $2013,5$. 100.Gadd, G.M. Bioremedial potential of microbial mechanisms of metal mobilization and immobilization. Current opinion in biotechnology 2000, 11, 271-9, https://doi.org/10.1016/S0958-1669(00)00095-1.

101.Lahori, A.H.; Zhang, Z.; Guo, Z.; Mahar, A.; Li, R.; Awasthi, M.K.; Sial, T.A.; Kumbhar, F.; Wang, P.; Shen, F.; Zhao, J. Potential use of lime combined with additives on (im) mobilization and phytoavailability of heavy metals from $\mathrm{Pb} / \mathrm{Zn}$ smelter contaminated soils. Ecotoxicology and environmental safety 2017, 145, 313-23, https://doi.org/10.1016/j.ecoenv.2017.07.049.

102.Kumar, PN.; Dushenkov, V.; Motto, H.; Raskin, I. Phytoextraction: the use of plants to remove heavy metals from soils. Environmental science \& technology. 1995, 29, 1232-8, https://doi.org/10.3390/ijms20143412.

103.DalCorso, G.; Fasani, E.; Manara, A.; Visioli, G.; Furini, A. Heavy metal pollutions: state of the art and innovation in phytoremediation. International journal of molecular sciences 2019, $20,3412$.

104.Sankhla, M. S..; \& Kumar, R. Contaminant of Heavy Metals in Groundwater \& its Toxic Effects on Human Health \& Environment. Int. J. Environ Sci Nat Res. 2019, 18, https://doi.org/10.19080/IJESNR.2019.18.555996.

105.Jabeen, R.; Ahmad, A.; Iqbal, M. Phytoremediation of heavy metals: physiological and molecular mechanisms. The Botanical Review 2009, 75, 339-64.

106. Denton, B. Advances in phytoremediation of heavy metals using plant growth promoting bacteria and fungi MMG 445 Basic Biotechnol 2007, 3, 1-5.

107.Assunção, A.G.; Schat, H.; Aarts, M.G. Thlaspi caerulescens, an attractive model species to study heavy metal hyperaccumulation in plants. New Phytologist 2003, 159, 351-60.

108. Sheoran, V.; Sheoran, AS.; Poonia, P. Role of hyperaccumulators in phytoextraction of metals from contaminated mining sites: a review. Critical Reviews in Environmental Science and Technology 2010, 41, $168-214$.

109. Cluis, C. Junk-greedy greens: phytoremediation as a new option for soil decontamination. BioTeach Journal. 2004, 2, 1-67.

110.Tong, Y.P.; Kneer, R.; Zhu, Y.G. Vacuolar compartmentalization: a second-generation approach to engineering plants for phytoremediation. Trends in plant science 2004, 9, 7-9.

111. Greipsson, S., Phytoremediation. Nat. Educ. Knowl 2011, 2, 7. 
112.Nguyen, T.Q.; Sesin, V.; Kisiala, A.; Emery, R.N. Phytohormonal roles in plant responses to heavy metal stress: implications for using macrophytes in phytoremediation of aquatic ecosystems. Environmental Toxicology and Chemistry 2021, 40, 7-22, https://doi.org/10.1002/etc.4909.

113. Hall, JÁ. Cellular mechanisms for heavy metal detoxification and tolerance. Journal of experimental botany 2002, 53, 1-1.

114. Sharma, SS.; Dietz, KJ. The significance of amino acids and amino acid-derived molecules in plant responses and adaptation to heavy metal stress. Journal of experimental botany 2006, 57, 711-26, https://doi.org/10.1093/jxb/erj073.

115.Navari-Izzo, F.; Quartacci, MF. Phytoremediation of metals: tolerance mechanisms against oxidative stress. Minerva Biotecnologica 2001, 13, 73.

116. Raskin, I.; Smith, RD.; Salt, DE. Phytoremediation of metals: using plants to remove pollutants from the environment. Current opinion in biotechnology 1997, 8, 221-6.

117. Cunningham, SD.; Ow, DW. Promises and prospects of phytoremediation. Plant physiology 1996, $110,715$.

118. Banuelos, GS.; Ajwa, HA.; Mackey, B.; Wu, L.; Cook, C.; Akohoue, S.; Zambruzuski, S. Evaluation of different plant species used for phytoremediation of high soil selenium. American Society of Agronomy, Crop Science Society of America, and Soil Science Society of America 1997, https://doi.org/10.2134/jeq1997.00472425002600030008x.

119. Ashraf, M.; Ozturk, M.; Ahmad, MS. Toxins and their phytoremediation. In Plant adaptation and phytoremediation Springer, Dordrecht 2010, 1-32.

120.Sas-Nowosielska, A.; Kucharski, R.; Małkowski, E.; Pogrzeba, M.; Kuperberg, JM.; Kryński, KJ. Phytoextraction crop disposal-an unsolved problem. Environmental pollution 2004, 128, 373-9, https://doi.org/10.1016/j.envpol.2003.09.012.

121.Susaria, S.; Bacckus, S.T.; McCutcheon, S.C.; Wolfe, N.L. Potential species for phytoremediation of perchlorate Diane Publishing Company 1999.

122.Salt, D.E. Phytoextraction: present applications and future promise. In: Wise, D.L.; Trantolo, D.J.; Cichon, E.J.; Inyang, H.I.; Stottmeister, U. (Eds.), Bioremediation of Contaminated Soils. Marcel Dekker, New York 2000.

123.Weiss, J.; Hondzo, M.; Biesboer, D.; Semmens, M. Laboratory study of heavy metal phytoremediation by three wetland macrophytes. International Journal of Phytoremediation 2006, 8, 245-59, https://doi.org/10.1080/15226510600846798.

124.Memon, A.R.; Schröder, P. Implications of metal accumulation mechanisms to phytoremediation. Environmental Science and Pollution Research 2009, 16, 162-75, https://doi.org/10.1007/s11356-008-0079$\mathrm{z}$.

125.Devi, P.; Kumar, P. Concept and application of phytoremediation in the fight of heavy metal toxicity. Journal of Pharmaceutical Sciences and Research 2020, 12, 795-804.

126. Gieroń, Ż.; Sitko, K.; Małkowski, E. The Different Faces of Arabidopsis arenosa-A Plant Species for a Special Purpose. Plants 2021, 10, 1342, https://doi.org/10.3390/plants10071342.

127.Zhang, H.; Heal, K.; Zhu, X.; Tigabu, M.; Xue, Y.; Zhou, C. Tolerance and detoxification mechanisms to cadmium stress by hyperaccumulator Erigeron annuus include molecule synthesis in root exudate. Ecotoxicology and Environmental Safety 2021, 219, 112359, https://doi.org/10.1016/j.ecoenv.2021.112359.

128.Dimitrakopoulos, P.G.; Aloupi, M.; Tetradis, G.; Adamidis, G.C. Broomrape Species Parasitizing Odontarrhena lesbiaca (Brassicaceae) Individuals Act as Nickel Hyperaccumulators. Plants 2021, 10, 816, https://doi.org/10.3390/plants10040816.

129.McGrath, S.P.; Zhao, F.J. Phytoextraction of metals and metalloids from contaminated soils. Current opinion in biotechnology 2003, 14, 277-82.

130.Rascio, N.; Navari-Izzo, F. Heavy metal hyperaccumulating plants: how and why do they do it? And what makes them so interesting?. Plant science 2011, 180, 169-81.

131.Verma, R. K.; Sankhla, M. S.; \& Kumar, R. Mercury Contamination in Water \& Its Impact on Public Health. International Journal of Forensic Science, 2018, 1.

132.Pivetz, B.E. Phytoremediation of contaminated soil and ground water at hazardous waste sites. US Environmental Protection Agency, Office of Research and Development, Office of Solid Waste and Emergency Response 2001.

133. Schnoor, J.L. Technology evaluation report: Phytoremediation of soil and groundwater. GWRTAC Series TE02-01 2002. 
134.Mahar, A.; Wang, P.; Ali, A.; Awasthi, M.K.; Lahori, A.H.; Wang, Q.; Li, R.; Zhang, Z. Challenges and opportunities in the phytoremediation of heavy metals contaminated soils: a review. Ecotoxicology and environmental safety 2016, 1, 111-21.

135.Sonone, S. S.; Jadhav, S., Sankhla, M. S., \& Kumar, R. Water Contamination by Heavy Metals and their Toxic Effect on Aquaculture and Human Health through Food Chain. Letters in applied NanoBioScience, 2020, 10, 2148-2166, https://doi.org/10.33263/LIANBS102.21482166

136. Andersson-Sköld, Y.; Enell, A.; Blom, S.; Rihm, T.; Angelbratt, A.; Haglund, K.; Wik, O.; Bardos, P.; Trac, T.; Keuning, S. Biofuel and other biomass based products from contaminated sites-Potentials and barriers from Swedish perspectives 2009.

137.Heaton, A.C.; Rugh, C.L.; Wang, N.J.; Meagher, R.B. Phytoremediation of mercury-and methylmercurypolluted soils using genetically engineered plants. Journal of soil contamination 1998, 7, 497-509, https://doi.org/10.1080/10588339891334384.

138.Eapen, S.; D'souza, S.F. Prospects of genetic engineering of plants for phytoremediation of toxic metals. Biotechnology advances 2005, 23, 97-114, https://doi.org/10.1016/j.biotechadv.2004.10.001.

139.Gisbert, C.; Ros, R.; De Haro, A.; Walker, D.J.; Bernal, M.P.; Serrano, R.; Navarro-Aviñó, J. A plant genetically modified that accumulates $\mathrm{Pb}$ is especially promising for phytoremediation. Biochemical and biophysical research communications 2003, 303, 440-5, https://doi.org/10.1016/S0006-291X(03)003498.

140.Conner, A.J.; Glare, T.R.; Nap, J.P. The release of genetically modified crops into the environment: Part II. Overview of ecological risk assessment. The Plant Journal 2003, 33, 19-46, https://doi.org/10.1046/j.09607412.2002.001607.x.

141.Kärenlampi, S.; Schat, H.; Vangronsveld, J.; Verkleij, J.A.; van der Lelie, D.; Mergeay, M.; Tervahauta, AI. Genetic engineering in the improvement of plants for phytoremediation of metal polluted soils. Environmental pollution 2000, 107, 225-31.

142.Pilon-Smits, E.; Pilon, M. Phytoremediation of metals using transgenic plants. Critical reviews in plant sciences 2002, 21, 439-56, https://doi.org/10.1080/0735-260291044313.

143.Clemens, S.; Palmgren, M.G.; Krämer, U.A. long way ahead: understanding and engineering plant metal accumulation. Trends in plant science 2002, 7, 309-15, https://doi.org/10.1016/S1360-1385(02)02295-1.

144.Davison, J. Risk mitigation of genetically modified bacteria and plants designed for bioremediation. Journal of Industrial Microbiology and Biotechnology, 2005, 32, 639-50, https://doi.org/10.1007/s10295-005-02421.

145.Ohara, K.; Kokado, Y.; Yamamoto, H.; Sato, F.; Yazaki, K. Engineering of ubiquinone biosynthesis using the yeast coq2 gene confers oxidative stress tolerance in transgenic tobacco. The Plant Journal 2004, 40, 73443, https://doi.org/10.1111/j.1365-313X.2004.02246.x.

146. Mengoni, A.; Gonnelli, C.; Galardi, F.; Gabbrielli, R.; Bazzicalupo, M. Genetic diversity and heavy metal tolerance in populations of Silene paradoxa L. (Caryophyllaceae): a random amplified polymorphic DNA analysis. Molecular ecology 2000, 9, 1319-24.

147. Mehta, V.; Kansara, R.; Srivashtav, V.; Savaliya, P. A Novel Insight into Phytoremediation of Heavy Metals through Genetic Engineering and Phytohor-mones. J Nanosci Nanomed Nanobio 2021, 4, 010.

148. Shah, V.; Daverey, A. Phytoremediation: A multidisciplinary approach to clean up heavy metal contaminated soil. Environmental Technology \& Innovation. 2020, 18, 100774, https://doi.org/10.1016/j.eti.2020.100774.

149.Remigio, A.C.; Chaney, R.L.; Baker, A.J.; Edraki, M.; Erskine, P.D.; Echevarria, G.; van der Ent, A. Phytoextraction of high value elements and contaminants from mining and mineral wastes: opportunities and limitations. Plant and Soil 2020, 449, 11-37, https://doi.org/10.1007/s11104-020-04487-3.

150. Yadav, K.K.; Singh, J.K.; Gupta, N.; Kumar, V.J. A review of nanobioremediation technologies for environmental cleanup: a novel biological approach. J Mater Environ Sci. 2017, 8, 740-57.

151.Singh, B.K. Organophosphorus-degrading bacteria: ecology and industrial applications. Nature Reviews Microbiology 2009, 7, 156-64, https://doi.org/10.1038/nrmicro2050.

152.Pateriya A, Verma RK, Sankhla MS, Kumar R. Heavy metal toxicity in rice and its effects on human health. Lett Appl NanoBio Sci. 2020, 10, 1833-45, https://doi.org/10.33263/LIANBS101.18331845.

153.Sajid, M.; Ilyas, M.; Basheer, C.; Tariq, M.; Daud, M.; Baig, N.; Shehzad, F. Impact of nanoparticles on human and environment: review of toxicity factors, exposures, control strategies, and future prospects. Environmental Science and Pollution Research. 2015, 22, 4122-43, https://doi.org/10.1007/s11356-0143994-1.

154.Paul, S. Chapter-6 Application of Nanoparticles in the Prospect of Remediation Strategy. CHEMICAL SCIENCES 2020, 1, 107. 
155.Kanwar, VS.; Sharma, A.; Srivastav, AL.; Rani, L. Phytoremediation of toxic metals present in soil and water environment: a critical review. Environmental Science and Pollution Research. 2020, 27, 1-26, https://doi.org/10.1007/s11356-020-10713-3.

156.Lee S.W, Kim J.H, Cha S.M. Analysis of the relation between pollutant loading and water depth flowrate changes in a constructed wetland for agricultural nonpoint source pollution management. Ecological Engineering 2020, 152, 105841, https://doi.org/10.1016/j.ecoleng.2020.105841.

157.Yang, Y.; Liu, Y.; Li, Z.; Wang, Z.; Li, C.; Wei, H. Significance of soil microbe in microbial-assisted phytoremediation: an effective way to enhance phytoremediation of contaminated soil. International Journal of Environmental Science and Technology. 2020, 17, 2477-84. https://doi.org/10.1007/s13762-020-02668-2.

158. Yu, B.; Peng, Y.; Xu, J.; Qin, D.; Gao, T.; Zhu, H.; Zuo, S.; Song, H.; Dong, J. Phytoremediation potential of Youngia japonica (L.) DC: a newly discovered cadmium hyperaccumulator. Environmental Science and Pollution Research. 2021, 28, 6044-57, https://doi.org/10.1007/s11356-020-10853-6.

159.Raj, D.; Maiti, SK. Brassica Juncea (L.) Czern. (Indian Mustard): A Potential Candidate for the Phytoremediation of Mercury from Soil. InSustainability in Environmental Engineering and Science. Springer Nature 2021, 67-72, https://doi.org/10.1007/978-981-15-6887-9_7.

160. Verma, P.; Rawat, S. Rhizoremediation of Heavy Metal-and Xenobiotic-Contaminated Soil: An Eco-Friendly Approach. In Removal of Emerging Contaminants Through Microbial Processes Springer, Singapore 2021, 95-113, https://doi.org/10.1007/978-981-15-5901-3_5.

161. Verma, A.; Roy, A, Bharadvaja N. Remediation of heavy metals using nanophytoremediation. InAdvanced oxidation processes for effluent treatment plants, Elsevier, 2021, 1, 273-296, https://doi.org/10.1016/B9780-12-821011-6.00013-X.

162. Wang, M.; Chen, S.; Li, N.; Ma, Y. A review on the development and application of nanoscale amendment in remediating polluted soils and waters. Zhongguo Shengtai Nongye Xuebao/Chinese Journal of EcoAgriculture. 2010, 18, 2, 434-9, https://doi.org/10.3724/SP.J.1011.2010.00434.

163. Verma, R. K., Sankhla, M. S., Rathod, N. V., Sonone, S. S., Parihar, K., \& Singh, G. K. Eradication of Fatal Textile Industrial Dyes by Wastewater Treatment 2021, 12, 567587, https://doi.org/10.33263/BRIAC121.567587. 